\begin{tabular}{c}
\hline KeMAS 16 (1) (2020) 53-60 \\
Jttp://journal.unnes.ac.id/nju/index.php/kemas
\end{tabular}

\title{
Comparison of Musculoskeletal Disorder Risk based on Gender in High School Students
}

Putri Winda Lestari ${ }^{\bowtie}$, Yunita Sari Purba, Agung Cahyono Tribuwono

Occupational Health and Safety, Faculty of Public Health, Universitas Binawan, Indonesia

\section{Article Info}

Article History:

Submitted October 2019

Accepted March 2020

Published July 2020

\section{Keywords:}

Gender, musculoskeletal

disorder, high

school students

\section{DOI}

https://doi.org/10.15294/

kemas.v16i1.21610

\begin{abstract}
In Indonesia, there is a tendency for the emergence of musculoskeletal disorders (MSDs) in school-aged children. MSDs can cause disruption of daily activities, such as lost school time. Individual factors such as sex can be the cause of MSDs. This study aims to determine how much gender differences affect the risk of musculoskeletal disorder. The design of this research was analytic observative with cross-sectional approach. The population is all high school students in the Kec. Kramat Jati East Jakarta as many as 4,708 students. The research sample was 370 class XI students. Samples were taken by simple random sampling. The independent variable is gender while the dependent variable is MSDs. Retrieval of data by filling out the Nordic Body Map questionnaire. Data were processed univariately and bivariately with chi-square test. The results showed that there was a relationship between sex and musculoskeletal disorder. The value of $\mathrm{p}=0,000$ with a PR value $=1,131$ and $95 \% \mathrm{CI}=1,051-1,217$ which shows that female are more at risk 1,131 times having musculoskeletal disorder compared to male.
\end{abstract}

\section{Introduction}

Musculoskeletal disorders are very common health problem in all age groups and genders throughout the world (Vos T et al., 2012). Recent evidence suggests that musculoskeletal disorders are very common in school children and adolescents (Dianat et al., 2017). This has become a major health problem and has burdened people and communities (Shan et al., 2013; Scarabottolo et al., 2017). Even WHO puts neck pain and other musculoskeletal diseases as the fourth and tenth health problems, related to disability (Vos T et al., 2015).

In recent decades there has been an increase in complaints of shoulder, neck and back pain in adolescents (Hakala et al., 2002; Gheysvandi et al., 2019). Based on the literature, the incidence of neck, shoulder and spinal pain in school children and adolescents ranges from $7 \%$ to $74 \%$ (Dianat et al., 2018). Research in Poland showed that more than $70 \%$ of adolescents aged 10-19 years experience back pain (Agnieszka, et.al, 2017; Agnieszka \& Czaprowski, 2013). Research in Iran shows that the prevalence of symptoms of neck, shoulder, lower back and upper back pain respectively are 27.9\%, 20.7\%, 34, 3\% and 19.0\% (Dianat et al., 2018).

Based on data from primary health care in Australia, as many as 5.8 out of 100 children aged less than 18 years are indicated to have musculoskeletal disorder. It can be estimated that there are 880,000 musculoskeletal problems in children and adolescents per year in Australia (Britt et al., 2010; Henschke et al., 2014). In Indonesia alone, there are no national data related to the prevalence of musculoskeletal disorder. From 2013 to 2015, the category of musculoskeletal system diseases 
and connective tissue was ranked second for non-communicable diseases in Bandung (Adhania et al., 2016). Research in Denpasar showed that as many as $36.04 \%$ of high school students researched had musculoskeletal disorders (Wiguna \& Adiatmika, 2019).

The definition of musculoskeletal disorders (Musculoskeletal Disorders / MSDs) is a disorder of muscles, tendons, joints, vertebrae, and nerves. The symptoms of MSDs that are commonly felt by a person are stiff neck and back; shoulder pain, stiffness or loss of flexibility; hands and feet aching like being pricked; elbows or ankles experience pain, swelling and stiffness; the finger loses mobility, stiffness and loss of strength; feet and heels feel tingling, cold, stiff or hot sensation.

The condition of muscle pain can cause disruption of daily activities, such as lost school time (Michael et al., 2007), as well as an impact on their physical and psychological health (Gheysvandi et al., 2019). Non-disappearing musculoskeletal pain increases the risk of disability and is associated with decreased muscle strength, decreased range of motion problems, and balance (Hunter et al., 2004).

Some factors that cause MSDs are excessive muscle stretching, repetitive activities, unnatural work attitudes (Sumardiyono \& Ada, 2014; Agustin, 2012), duration, as well as environmental and psychosocial factors. Individual factors such as age, gender, smoking, physical activity, physical strength, and body size can also be a cause of MSDs. This research objective is to determine how much gender differences affect the risk of musculoskeletal disorder.

Method

This research is an observational analytic research with cross sectional design. It was conducted in March - October 2019 in high schools located in Kec. Kramat Jati, East Jakarta. The population was all high school students in the district Kramat Jati, East Jakarta, totaling 4,708 students. Based on the sampling formula, a minimum sample of 370 students was obtained. Students who were sampled were students of class XI. The method of sampling is simple random sampling. This study has passed the ethics committee with ethical clearance number 232 / KEPK-POLKESMA / 2019.
The independent variable in this research is gender while the dependent variable is musculoskeletal disorder. The instrument was the Nordic Body Map questionnaire. There were 28 parts of the body that were asked in relation to musculoskeletal disorder. The measurement scale used was the Guttman scale, which consists of two choices of answers, there are complaints (yes) and no complaints musculoskeletal disorder. The questionnaire had been tested for validity and reliability. Data collection techniques is by filling out a questionnaire. Before the respondent fills in the questionnaire, the researcher gives an explanation before approval then the respondent will fill in the agreement.

Data analysis was carried out univariately, that is, every variable studied would be seen its frequency distribution and bivariately, namely between independent and dependent variables would be cross tabulated. The statistical test used was the chi square test with a significance limit $\alpha=0.05$ and a 95\% Confidence Interval and the PR (Prevalence Ratio) value is analyzed. The data was presented by narration, cross tables and graphs.

\section{Result and Discussion}

The total respondents were 370 students, of which 164 students (44.30\%) were male and 206 students (55.70\%) were female. A total of 334 students consisting of 196 female students and 138 male students said experiencing musculoskeletal disorder (90.30\%). While as many as 36 students consisting of 10 female students and 26 male students did not experience musculoskeletal disorder (9.70\%).

The most limbs got muscular pain were right shoulder (49.73\%), back (49.19\%), left shoulder (43.78\%), waist (38.92\%) and upper neck $(37.84 \%)$. While the limbs that were the least experiencing muscular pain were the left elbow (7.03\%), right elbow (7.84\%), buttocks (bottom) (9.73\%), left hand (11.08\%) and arms bottom left (11.62\%). (Image 1)

Female had the highest musculoskeletal disorder in the right shoulder (62.62\%), back (62.62\%), left shoulder (54.85\%), waist (46.60\%) and upper neck (42.72\%). While the limbs that were least complained were left elbow (7.28\%), right elbow (8.25\%), bottom (9.22\%), left hand $(12.14 \%)$ and buttock (13.11\%). Male had 


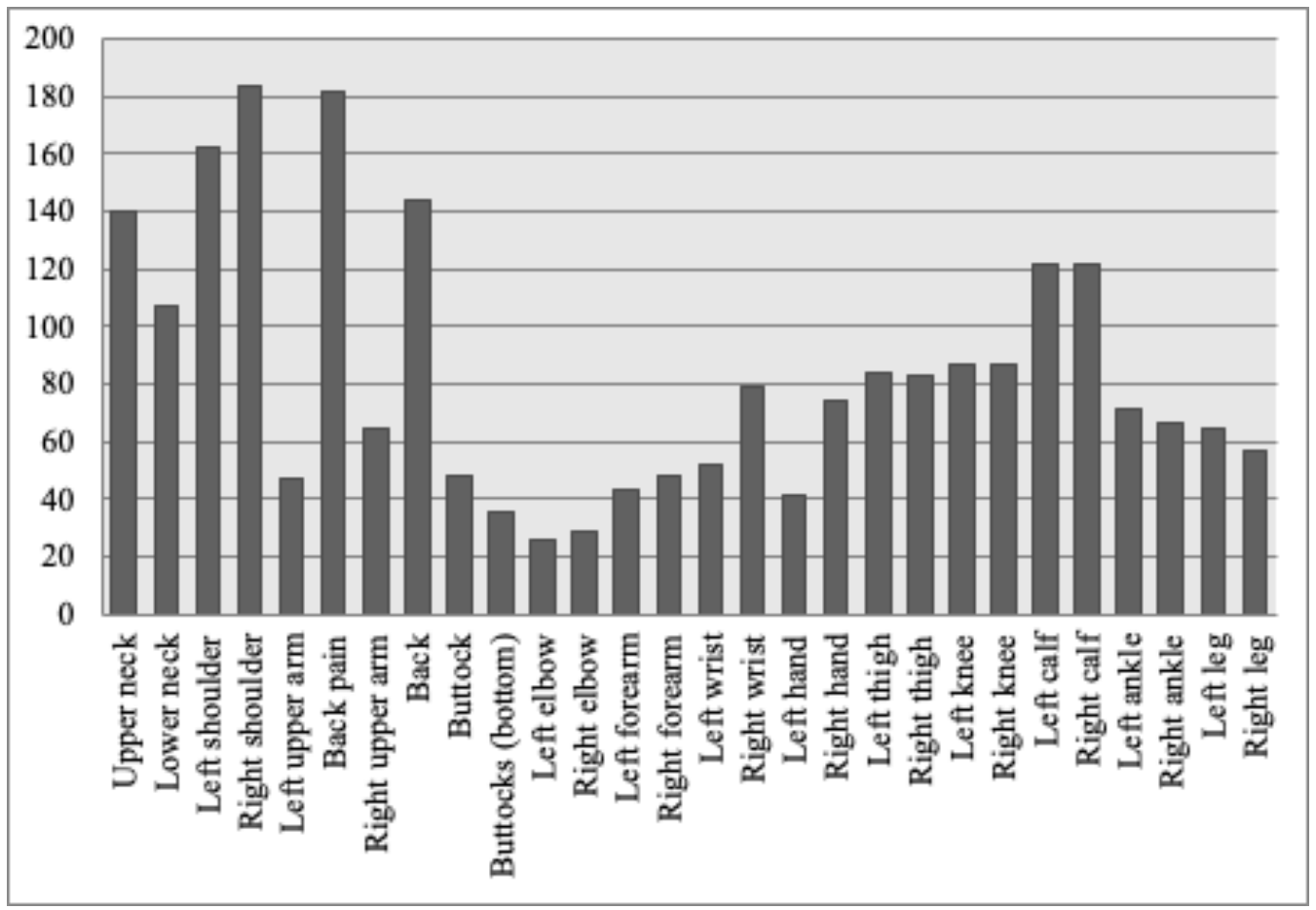

Image 1. Distribution of Limbs Experiencing Musculoskeletal Disorder

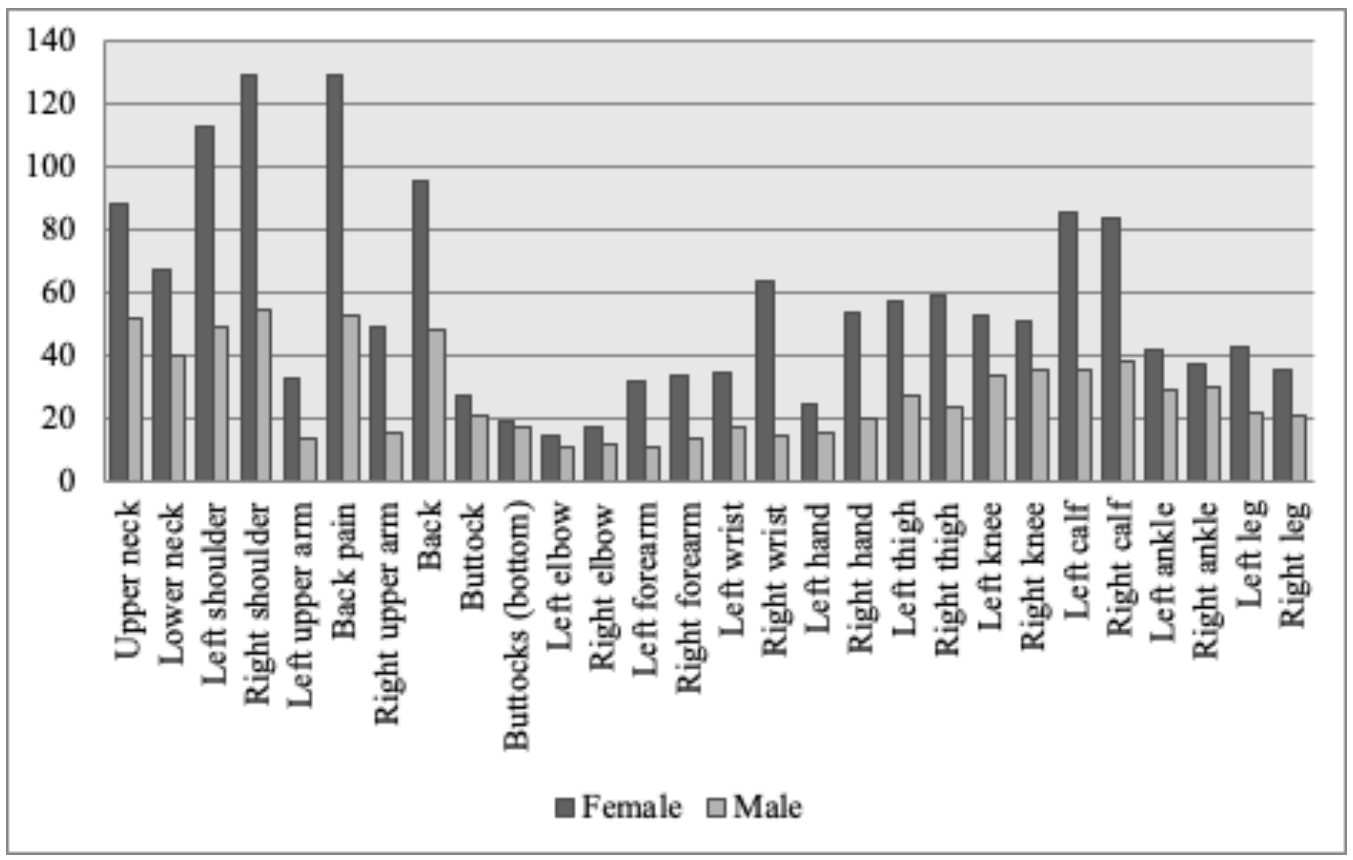

Image 2. Distribution of Limbs Experiencing Musculoskeletal Disorder Based on Gender

the highest musculoskeletal disorder in the right shoulder (33.5\%), back (32.32\%), upper neck $(31.71 \%)$, left shoulder (29.88\%), waist (29.27\%). The least complained body parts for male were left elbow (6.71\%), left forearm
(6.71\%), right elbow (7.32\%), right forearm (8.54\%), left upper arm ( 8.54\%). (Image 2)

The highest distribution of musculoskeletal disorder for both female and male was the same in the right shoulder, back, 
Putri Winda Lestari, et al / Comparison of Musculoskeletal Disorder Risk

Table 1. Chi Square Analysis Result on Gender and Musculoskeletal Disorder

\begin{tabular}{|c|c|c|c|c|c|c|}
\hline \multirow[t]{2}{*}{ Gender } & \multicolumn{2}{|c|}{ Musculoskeletal Disorder } & \multirow{2}{*}{ Total } & \multirow{2}{*}{$\mathrm{p}$ value } & \multirow{2}{*}{ PR } & \multirow{2}{*}{$95 \% \mathrm{CI}$} \\
\hline & Yes & No & & & & \\
\hline \multirow{3}{*}{$\begin{array}{l}\text { Female } \\
\text { Male }\end{array}$} & 196 & 10 & 206 & \multirow{3}{*}{0,000} & \multirow{3}{*}{1,131} & \multirow{3}{*}{$1,051-1,217$} \\
\hline & 138 & 26 & 164 & & & \\
\hline & 334 & 36 & 370 & & & \\
\hline
\end{tabular}

left shoulder, waist and upper neck. However, the distribution of musculoskeletal disorders that is most rarely felt was different. The most rarely complained part of female body was bottom, left hand and buttock. While male rarely felt pain in the left forearm, right forearm, and left upper arm. Both gender stated the right elbow and the left elbow as the limbs that were least complained of having musculoskeletal disorder.

Of the total 206 female students, them who experienced musculoskeletal disorder as many as 196 students and who did not experience musculoskeletal disorder as many as 10 students. From a total of 164 male students, them who experienced musculoskeletal disorder as many as 138 students and who did not experience musculoskeletal disorder as many as 26 people. Based on the chi-square test, the value of $p=0,000$ shows that there is a relation between gender and the incidence of musculoskeletal disorder. PR values 1.131 and $95 \% \mathrm{CI}=1.051-1.217$, which shows that female have a risk of 1.131 times higher to get musculoskeletal disorders compared to male. (Table 1).

Gender greatly affects the risk level of muscle complaints. This research is in line with Shan's research in Shanghai which showed that gender is a risk factor for complaints of muscle pain (Shan et al., 2013). Female correlates with higher rates of musculoskeletal disorder (Laura et al., 2018). This happens because physiologically, female muscle ability is lower than male. Female has smaller muscle fibers compared to male so that in general female muscle strength is weaker than male. (Barus et al., 2010) Samsoe's research showed that for most muscle groups, male is 1.5 to 2 times stronger than female. The oldest male has powers similar to the youngest female. In all age groups, female has lower muscle strength than men. Male muscle strength decreases with age, while female muscle strength decreases from 41 years (Samsøe et al., 2009).

Other research shows that isometric muscle strength in boys develops more clearly starting at the age of 10 years and peaking at the ages of 14 and 15 years. While the isometric muscle strength of girls is lower when compared to boys, especially starting at the age of 10 years (Maria et al., 2018).

This research shows that in the neck and shoulders, female complain more pain than men. The comparison of musculoskeletal disorders in the neck and shoulders between female and male is $4: 3$ for the upper neck, $3: 2$ for the lower neck, 5: 3 for the left shoulder and 2: 1 for the right shoulder (Image 4).

Epidemiological studies have identified female as being more prone to developing musculoskeletal disorders in the neck-shoulder area when doing low strength, and repetitive work. Work-related MSDs have consistently been reported to occur at a greater rate among female than male (Schneider and Irastorza, 2010) and especially for the neck and shoulder / arm area (Nordander et al., 2016; Srinivasan et al., 2016; Nordander et al., 2016). Neck and shoulder pain in children is considered a risk factor for health problems in adulthood. Therefore, detecting and understanding pain and treating it early is needed to prevent further effects (Gheysvandi et al., 2019).

This research shows that for the arm, female complain more pain than male. The comparison of musculoskeletal disorders in the arms between female and male is 2:1 for the left upper arm, 5:2 for the right upper arm, 2:1 for the left forearm and 2:1 for the right forearm. Following are the percentages of pain in the neck, shoulders and arms for both. (Image 3)

The results of this research indicate that in the lower extremities, female complain more pain than male (Image 4).

Male have larger mCSA (muscle cross 


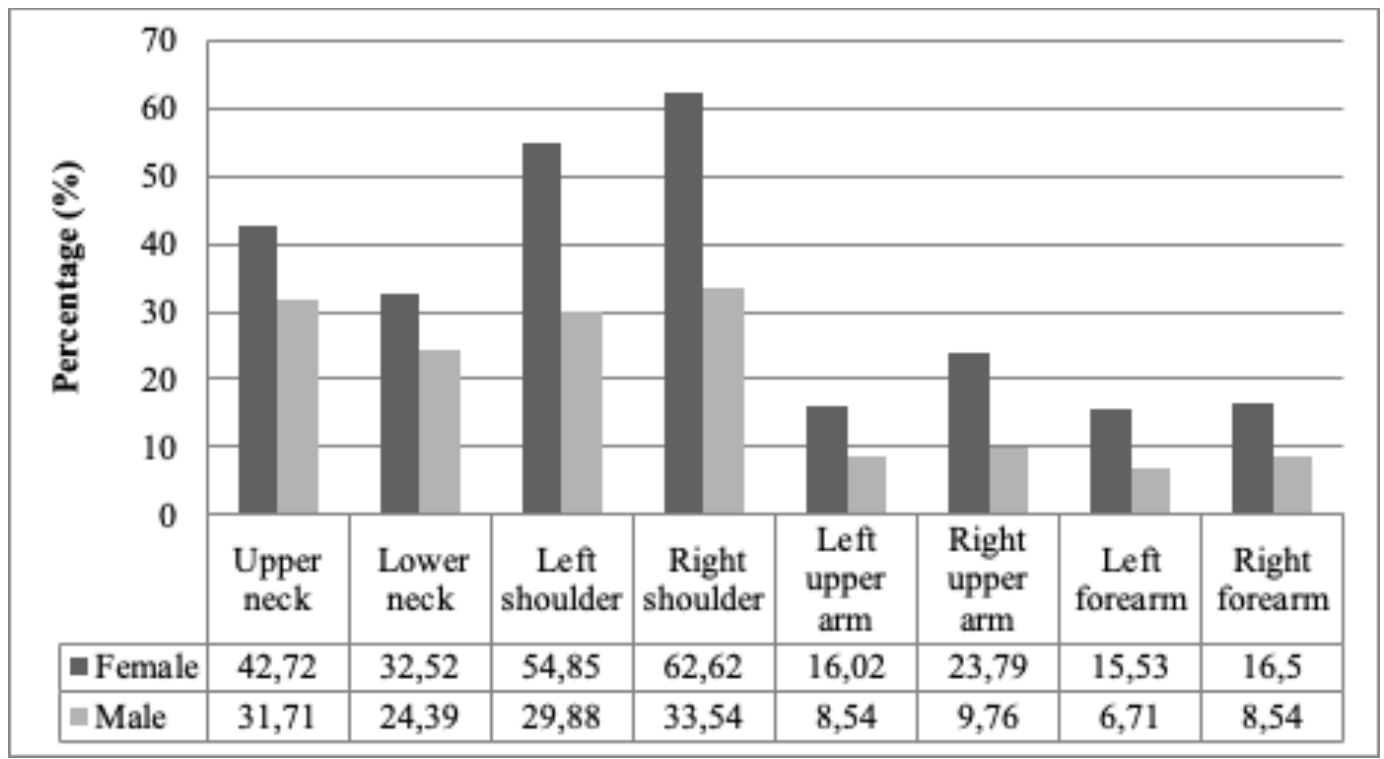

Image 3. Comparison of Musculoskeletal Disorder on Neck, Shoulder and Arms between Female and Male

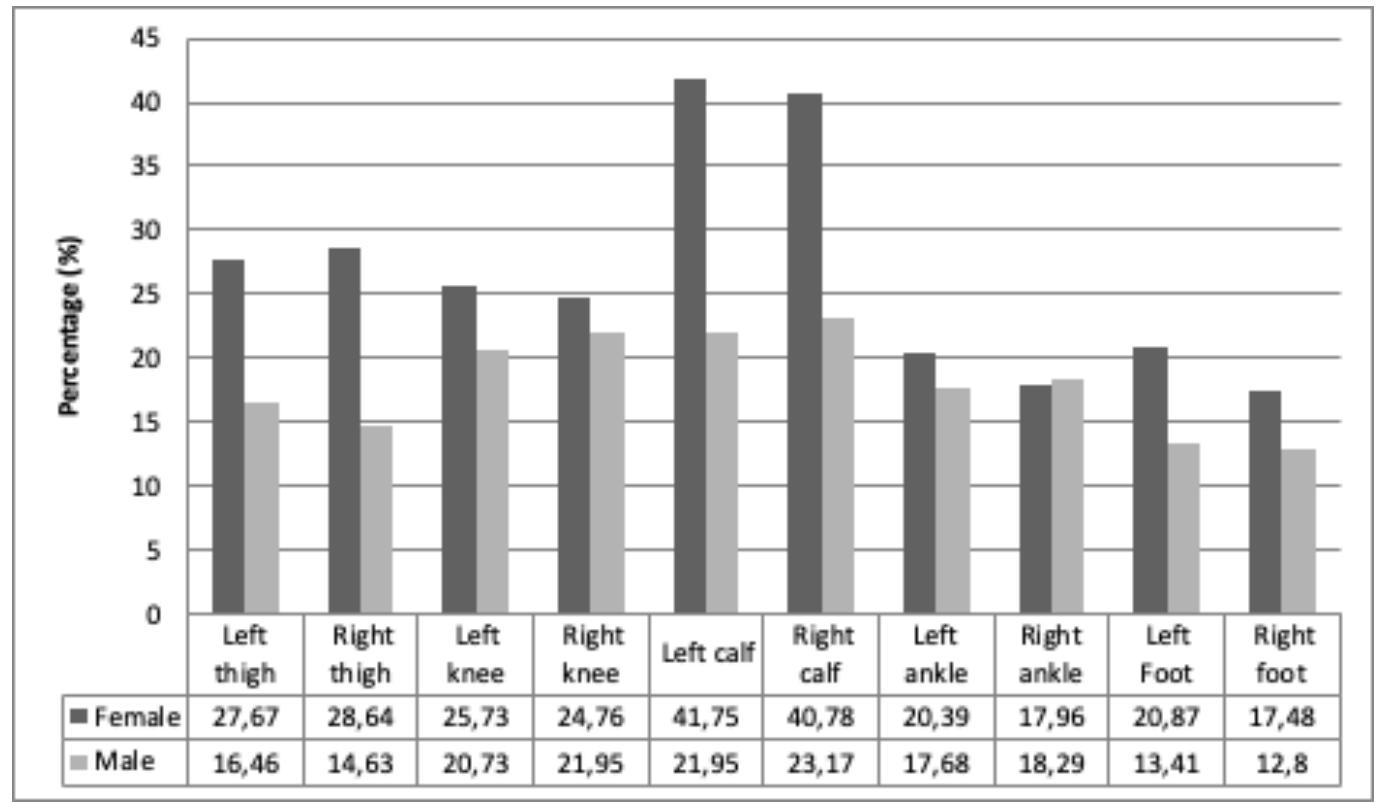

Image 4. Comparison of Musculoskeletal Disorder on Lower Extremities between Female and Male

sectional area) in both arms than female. And also have $1 \mathrm{RM}$ (repetition maximum) greater in the dominant arm than female, but there is no difference in the non-dominant arm (Tanton et al., 2009).

Snih Soham's research on lower extremity muscle strength showed that the average muscle strength for male ranges from $9.3 \mathrm{~kg}$ for knee extension, $12.8 \mathrm{~kg}$ for hip flexion, to $13.0 \mathrm{~kg}$ for hip abduction. As for female, the average strength ranges from $6.6 \mathrm{~kg}$ for knee extension,
$9.5 \mathrm{~kg}$ for hip flexion, up to $8.6 \mathrm{~kg}$ for hip abduction. The average physical function score was 70.7 for male and 60.6 for female (Snih et al., 2005).

Increasing muscle size is generally parallel with increasing strength, and vice versa decreasing muscle size has very high correlation with decreasing strength. Muscle function and physical ability decrease with the loss of muscle mass (Breuille et al., 2019).

Loss of muscle mass has been linked 
to decreased walking speed and reduced leg strength. In addition, reduced muscle strength and size also increase the risk of falls, injury to bones, pain and discomfort, osteoporosis, loss of functional capacity, weakness, disability, obesity, and diabetes (Sowers et al., 2005). Loss of strength and muscle size causes a decrease in overall quality of life, inhibits physical activity, reduces energy expenditure, and increases body fat which can increase dyslipidemia and reduce insulin sensitivity (Hunter et al., 2004). Musculoskeletal pain that does not disappear increases the risk of disability and is associated with decreased muscle strength, decreased range of motion problems, and balance (Hunter et al., 2004).

Some conditions such as repetition, dynamic / static load, attitude / body position, lack of rest and so on contribute a risk factor for the emergence of musculoskeletal disorders. In school students where they spend more time with sitting postures, the risk of experiencing musculoskeletal disorders especially if the chair or table used is not ergonomic. When sitting for a long time, the body's muscles become passive. Therefore stretching is necessary to prevent muscle stiffness. The existence of stretching can increase flexibility, improve posture, maintain physical fitness and reduce the risk of musculoskeletal disorders.

Overall, female has lower muscle strength than male. So it is more susceptible to experiencing muscle pain or musculoskeletal disorders. These complaints are more common, for example when experiencing a menstrual cycle. Female experience an increase in muscle tension suddenly before menstruation and a decrease after menstruation. In addition, the habit of using high heels can also cause low back pain. Therefore, besides stretching, female students are expected to reduce the use of high heels.

\section{Conclussion}

There is a relation between gender and the incidence of musculoskeletal disorder. $p$ value $=0,000$ with a $P R$ value of 1,131 and $95 \%$ $\mathrm{CI}=1,051-1,217$ which shows that female are 1,131 times more likely to get musculoskeletal disorder than men. Corrective action that can be done is to provide education to students regarding risk factors for musculoskeletal disorder. For students who are more at risk of developing musculoskeletal disorder, routinely do exercises to improve muscle strength.

This research was completed with supports of many parties. The researcher would like to acknowledge DRPM RISTEKDIKTI and Binawan University for providing research grant funds. Also to the school for granting permission and the students who had become respondents in this study.

\section{Reference}

Adhania, C.C., Wiwaha, G., \& Fianza, P.I., 2016. Prevalensi Penyakit Tidak Menular pada Fasilitas Kesehatan Tingkat Pertama di Kota Bandung Tahun 2013-2015 Prevalence of Noncommunicable Diseases at Primary Healthcare in Bandung City in 2013-2015. JSK, 3(4), pp.204-211.

Agnieszka, K., \& Czaprowski, D., 2013. Epidemiology of Back Pain in Children and Youth Aged $10-19$ from the Area of the Southeast of Poland. BioMed Research International, 2013.

Agnieszka, K., Kolwicz-ga, A., Bochenek, A., \& Czaprowski, D., 2017. Back Pain in Physically Inactive Students Compared to Physical Education Students with A High and Average Level of Physical Activity Studying in Poland. BMC Musculoskeletal Disorders, 18(501), pp.1-8.

Agustin, C.P.M., 2012. Masa Kerja, Sikap Kerja dan Kejadian Sindrom Karpal pada Pembatik. Jurnal Kesehatan Masyarakat, 7(2), pp.170176.

Barus, A.P., Nusdwinuringtyas, N., Ratnawati, A., \& Widyahening, I.S., 2010. Pengaruh Electrical Stimulation terhadap Kekuatan Quadriceps Femoris Penderita PPOK Eksaserbasi dan Pasca Eksaserbasi Akut. Majalah Kedokteran Indonesia, 60(6), pp.273-278.

Breuille, D., Toshio, M., Pares, V., \& Gerard., 2019. Improvement In Muscle Functionality Of Elderly Males. United States Patent Application, 18.

Britt, H., Miller, G.C., Charles, J., Henderson, J., \& Bayram, C., 2010. General Practice Activity in Australia Bettering the Evaluation And Care of Health. Sydney: Australian Institute of Health and Welfare 2010.

Dianat, I., 2017. Risk Factors for Neck and Shoulder Pain Among Schoolchildren and Adolescents. Journal of Paediatrics and Child Health, 54(1), pp.1-8.

Dianat, I., Alipour, A., \& Jafarabadi, M.A., 2018. Multigroup Latent Class Model of Musculoskeletal Pain Combinations in 
Children/Adolescents : Identifying Highrisk Groups by Gender and Age. The Journal of Headache and Pain, 7(4), pp.1-8.

Gheysvandi, E., Dianat, I., Heidarimoghadam, R., Tapak, L., Karimi-shahanjarini, A., \& Shahkolai, F.R., 2019. Neck and Shoulder Pain Among Elementary School Students: Prevalence and Its Risk Factors. BMC Public Health, 19(1299), pp.1-11.

Hakala, P., Rimpela, A., Salminen, J.J., Virtanen, S.M., \& Rimpella, M., 2002. Back, Neck, and Shoulder Pain in Finnish Adolescents: National Cross Sectional Surveys. BMJ, 325, pp.12-15.

Henschke, N., Harrison, C., Mckay, D., Broderick, C., Latimer, J., Britt, H., \& Maher, C.G., 2014. Musculoskeletal Conditions in Children and Adolescents Managed in Australian Primary Care. BMC Musculoskeletal Disorders, 15(164), pp.1-8.

Hunter, G.R., Mccarthy, J.P., \& Bamman, M.M., 2004. Effects of Resistance Training on Older Adults. Sports Med, 34(5), pp.329-348.

Laura, G.K.A., Huisstede, B.M.A., Rob, G.H., Nelissen, H., Rietveld, A.B.M., \& Haitjema, S., 2018. The High Prevalence of PlayingRelated Musculoskeletal Disorders (PRMDS) and Its Associated Factors in Amateur Musicians Playing in Student Orchestras: A Cross- Sectional Study. Plos One, 13(2), pp.1-12.

Maria, L., Daloia, T., Maia, M., Figueiredo, L., Zangiacomi, E., \& Mattiello-sverzut, A.C., 2018. Brazilian Journal of Isometric Muscle Strength in Children and Adolescents Using Handheld Dynamometry: Reliability and Normative Data for The Brazilian Population. Brazilian Journal of Physical Therapy, 123, pp.1-11.

Michael, J., Gregory, L., \& Donna, L., 2007. Association of Relative Backpack Weight With Reported Pain, Pain Sites, Medical Utilization, and Lost School Time in Children and Adolescents. The Journal of School Health, 77(5), pp.232-239.

Nordander, C., Hansson, G.-åke, Ohlsson, K., Arvidsson, I., Balogh, I., Rittner, R., \& Skerfving, S., 2016. Exposure- Response Relationships For Work-Related Neck And Shoulder Musculoskeletal Disorders - Analyses Of Pooled Uniform Data Sets. Applied Ergonomics Journal, 55(2016), pp.70-84.

Samsøe, B.D., Lund, H., Stockmarr, A., Holm, C.C., \& Wa, I., 2009. Isokinetic and Isometric Muscle Strength in A Healthy Population with Special Reference to Age and Gender. Actra Physiol, 197, pp.1-68.

Scarabottolo, C.C., Pinto, R.Z., Oliveira, C.B., Zanuoti, E.F., Cardoso, J.R., \& Christofaro, D.G.D., 2017. Back and Neck Pain Prevalence and Their Association with Physical Inactivity Domains in Adolescents. European Spine Journal, 26(9), pp.2274-2280.

Schneider., \& Irastorza., 2010. OSH in Figures: Work-related Musculoskeletal Disorders in The EU - Facts and Figures. Luxembourg: Publications Office of the European Union.

Shan, Z., Deng, G., Li, J., Li, Y., Zhang, Y., \& Zhao, Q., 2013. Correlational Analysis of Neck/ Shoulder Pain and Low Back Pain with the Use of Digital Products, Physical Activity and Psychological Status among Adolescents in Shanghai. Plos One, 8(10), pp.1-9.

Snih, S., Al_Raji, M.A., Peek, K., \& Ottenbacher, K.J., 2005. Pain, Lower-Extremity Muscle Strength, and Physical Function A,png Older Mexican Americans. Arch Phys Med Rehabil, 86(July), pp.1394-1400.

Sowers, M.R., Crutchfield, M., Richards, K., Wilkin, M.K., Furniss, A., Jannausch, M., \& Zhang, D., 2005. Sarcopenia Is Related to Physical Functioning and Leg Strength in MiddleAged Women. Journal of Gerontology: Medical Sciences, 60(4), pp.486-490.

Srinivasan, D., Sinden, K.E., Erik, S., \& Julie, M., 2016. Gender Differences in Fatigability and Muscle Activity Responses to A Short-Cycle Repetitive Task. European Journal of Applied Physiology, 116(11-12), pp.2357-2365.

Sumardiyono., \& Ada, Y.R., 2014. Perbedaan Gangguan Muskuloskeletal Pembantik Wanita dengan DIngklik dan Kursi Kerja Ergonomis. Jurnal Kesehatan Masyarakat, 9(2), pp.144-149.

Tanton, L.C., Cappaert, T.A., Gordon, P.M., Zoeller, R.F., \& Angelopoulus, T.J., 2009. Strength , Size, and Muscle Quality in the Upper Arm Following Unilateral Training in Younger and Older Males and Females. Clinical Medicine: Arthritis and Musculoskeletal Disorders, 2(989), pp.9-18.

Vos, T., Barber, R.M.B.B., Bertozzi-Villa, A., Biryukov, S., Bolliger, I., \& Dicker, D., 2015. Global, Regional, and National Incidence, Prevalence, and Years Lived with Disability for 301 Acute and Chronic Diseases and Injuries in 188 Countries , 1990-2013: A Systematic Analysis for the Global Burden of Disease Study 2013. The Lancet, 6736(15), pp.1990-2013.

Vos, T., Flaxman, A.D., Naghavi, M., Lozano, R., 
Michaud, C., Ezzati, M., Corriere, M., 2012. Years Lived with Disability (YLDs) for 1160 Sequelae of 289 Diseases and Injuries 1990 2010: A Systematic Analysis for the Global Burden of Disease Study 2010. The Lancet,
380(9859), pp.2163-2196.

Wiguna, I.P.P., \& Adiatmika, I.P.G., 2019. Hubungan Berat Tas dengan Gangguan Muskuloskeletal pada Siswa SMAN 4 Denpasar. Intisari Sains Medis, 10(2), pp.338-341. 